\title{
PROSES BERPIKIR KREATIF SISWA SMP BERDASARKAN TAHAPAN WALLAS DALAM MEMECAHKAN MASALAH MATEMATIKA DITINJAU DARI TIPE KEPRIBADIAN EKSTROVERT - INTROVERT
}

\author{
Nurul Fitriana \\ Pendidikan Matematika, FMIPA, Universitas Negeri Surabaya, e-mail: nurulfitriana2@mhs.unesa.ac.id

\section{Endah Budi Rahaju} \\ Pendidikan Matematika, FMIPA, Universitas Negeri Surabaya, e-mail: endahrahaju@unesa.ac.id
}

\begin{abstract}
Abstrak
Proses berpikir kreatif rnerupakan salah satu cara untuk melihat persoalan dari banyak perspektif. Tahapan berpikir kreatif menurut Wallas meliputi persiapan, inkubasi, iluminasi, dan verifikasi. Perbedaan proses berpikir kreatif dalam menyelesaikan masalah matematika juga dipengaruhi perbedaan tipe kepribadian ekstrovert dan introvert pada siswa. Tujuan penelitian ini untuk mendeskripsikan proses berpikir kreatif siswa berdasarkan tahapan Wallas dalam memecahkan masalah matematika ditinjau dari tipe kepribadian ekstrovert dan introvert. Penelitian ini merupakan jenis penelitian deskriptif dengan metode pendekatan kualitatif yang dilaksanakan di kelas VIII SMP Negeri di Gresik tahun ajaran 2018/2019. Hasil penelitian menunjukkan: (1) proses berpikir kreatif siswa dengan tipe ekstrovert, (a) pada tahap persiapan, siswa membaca dan memahami soal dua kali dan siswa dapat menjelaskan kembali informasi yang di dapat menggunakan bahasanya sendiri. (b) pada tahap inkubasi, siswa mengalami titik jenuh dan tidak dapat menemukan solusi dan akhirnya melakukan gerakan fisik dengan alasan memikirkan solusi tersebut. (c) pada tahap iluminasi, siswa telah menemukan solusi untuk mencari keuntungan maksimal yaitu dengan melihat perbandingan yang sudah diketahui soal. (d) pada tahap verifikasi, siswa telah menerapkan dan melaksanakan ide yang telah ditetapkan, namun siswa tidak memeriksa kembali langkah-langkah dan hasil perhitungannya. (2) proses berpikir kreatif siswa dengan tipe introvert, (a) pada tahap persiapan, siswa membaca dan memahami soal beberapa kali dan subjek dapat menjelaskan kembali informasi yang didapat menggunakan bahasanya sendiri, (b) pada tahap inkubasi, siswa mengalami titik jenuh tetapi tetap memikirkan solusi namun sambil memainkan alat tulisnya. c) pada tahap iluminasi, siswa menemukan ide kunci yang mengarahkan pada pemecahan masalah yaitu mencari keuntungan maksimal dengan melihat perbandingan yang sudah diketahui soal. (d) pada tahap verifikasi, siswa telah menerapkan dan melaksanakan ide yang ditetapkan, siswa juga memeriksa kembali langkah-langkah dan hasil perhitungannya dari awal.
\end{abstract}

Kata Kunci : proses berpikir kreatif tahapan wallas, memecahkan masalah matematika, tipe kepribadian ekstrovert dan introvert

\begin{abstract}
The process of creative thinking is one way to look at problems from many perspectives. The stages of creative thinking according to Wallas of preparation, incubation, illumination, and verification. Differences in creative thinking processes in solving mathematical problems also affect differences in student's extrovert and introvert personality types. This study is purposed to describe the student's creative thinking processes based on the stages of Wallas with extrovert and introvert personality types. This research is a qualitative descriptive which conducted in 8th grade SMP Negeri in Gresik 2018/2019. The result showed that: 1) The creative thinking's process of students with extrovert types, (a) In the preparation stage, student could read and understand the questions twice based on subject's ability to explain back information using its own language. (b) In the incubation stage, student experienced a saturation point and could not find a solution. Then, student made physical movements for thinking about the solution. (c) In the illumination stage, student has found a solution to find the maximum benefit by looking at the already known comparisons of the problems. (d) In the verification stage, student has implemented its idea, but student did not re-examine the steps and the results. 2) The creative thinking's process of students with introvert types, (a) In the preparation stage, student could read and understand the questions several times based on subject's ability to explain back information using its own language. (b) In the incubation stage, student experienced a saturation point but still though the solution with playing the writing instrument. (c) In the
\end{abstract}


illumination stage, student found the main idea that lead to problem solving, namely seeking maximum profit by looking at the already known comparisons of the problems. (d) In the verification stage, student has implemented its idea, student also re-checked the steps and the results from the first stage.

Keywords : creative thinking process of wallas, solve mathematical problems, extrovert and introvert personality type

\section{PENDAHULUAN}

Permendikbud RI No. 20 Tahun 2016:3 tentang Standar Kompetensi Lulusan Pendidikan Dasar dan Menengah menjelaskan bahwa "setiap lulusan satuan pendidikan dasar dan menengah memiliki kompetensi pada tiga dimensi yaitu sikap, pengetahuan, dan keterampilan". Melalui pendekatan ilmiah yang sesuai dengan satuan pendidikan, pada dimensi keterampilan memiliki keterampilan berpikir dan bertindak yakni kreatif, produktif, kritis, mandiri, kolaboratif, dan komunikatif. Menurut Nurjannah (2016), matematika adalah mata pelajaran penting yang diajarkan di semua jenjang pendidikan termasuk jenjang SMP karena siswa dengan belajar matematika akan memiliki kemampuan berpikir kreatif dan bertindak efektif. Dengan demikian, pembelajaran matematika perlu menekankan kreativitas.

Kreativitas merupakan hasil dari proses berpikir kreatif. Santrock (terjemahan Bhimasena 2014:20) mendefinisikan bahwa "kreatif sebagai kemampuan untuk berpikir tentang cara baru, dan tidak biasa, dan datang dengan solusi yang unik". Berpikir kreatif sering didefinisikan sebagai berpikir divergen. Hal ini dijelaskan oleh McGregor (2007:168) yang mengemukakan bahwa "creativity, then involves divergent thinking the ability to come up with new, original ideas, which by its nature will be unusual". Lebih lanjut, McGregor (2007:169) menyatakan bahwa "creativity is the ability to see things in a new way, to see problems that no one else may even realize exist, and even develop new, unique, and effective solutions to these problems". Dapat dikatakan bahwa, seseorang yang berpikir kreatif dapat menggunakan keterampilan kognitif dan kemampuannya untuk menemukan solusi baru dari suatu masalah. Solusi tersebut dapat berupa pemikiran dan ide-ide yang baru dan berharga, yang diperoleh dari hasil menguraikan, menyempurnakan, menganalisis, dan mengevaluasi.

Menurut Silver (1997) terdapat tiga aspek penting dalam kreativitas, yaitu fluency, flexibility, dan novelty. Aspek fluency mengacu pada keberagaman jawaban yang diberikan siswa. Aspek flexibility mengacu keberagaman cara yang diberikan siswa dalam memecahkan masalah, sedangkan aspek novelty mengacu pada kemampuan menyelesaikan masalah. Untuk cara yang baru didapat dari kombinasi pengetahuan siswa sebelumnya.

Berikut ini dijelaskan empat tahapan dalam proses berpikir kreatif menurut Wallas (2014), yaitu
1) preparation, tahap pertama dari proses berpikir kreatif adalah tahap persiapan yakni ketika masalah yang ada diinvestigasi dari semua arah untuk memecahkannya.

(2) incubation, tahap kedua yakni tahap dimana individu berhenti sejenak untuk tidak memikirkan masalahnya dan perhatiannya fokus ke hal lain.

(3) illumination, tahap ketiga adalah tahap iluminasi yakni ketika masalah yang ada nampak dilupakan akan tetapi pada waktu yang tidak disangka-sangka jawaban untuk masalah tersebut muncul di pikiran.

(4) verification. tahap yang terakhir adalah tahap verifikasi yakni menguji pemahaman yang telah diperoleh dan membuat solusi dari masalah yang ada.

Menurut Siswono (2008: 39), "salah satu cara yang dapat mendorong kemampuan berpikir kreatif dalam pembelajaran matematika adalah dengan terbiasa memecahkan masalah". Individu yang memiliki kemampuan berpikir kreatif tidak hanya mampu menyelesaikan masalah non rutin, tetapi juga mampu menyelesaikan berbagai alternatif jawaban dari masalah yang diberikan. Jadi, berpikir kreatif memiliki hubungan yang sangat kuat dengan kemampuan pemecahan masalah.

Pemecahan masalah dapat meningkatkan kemampuan berpikir kreatif (Siswono, 2007). Hal tersebut juga didukung oleh Izzati (2009:1) "kemampuan berpikir kreatif merupakan bagian yang sangat penting untuk kesuksesan dalam pemecahan masalah". Tanpa adanya kreativitas dalam berpikir akan membuat siswa mengalami kesulitan dalam memecahkan masalah matematika, karena masalah matematika berbeda dengan soal latihan biasa. Jika soal latihan matematika diselesaikan dengan prosedur rutin maka masalah matematika tidak bisa diselesaikan dengan prosedur rutin. Masalah matematika diselesaikan dengan pemikiran yang kreatif sehingga muncul ide untuk menemukan solusi masalah yang diberikan.

Pemecahan masalah yang digunakan dalam penelitian ini yaitu pemecahan masalah Polya, karena langkah-langkah yang tersusun lebih runtut dan terstruktur secara sistematis sehingga dapat mempermudah siswa dalam menyelesaikan masalah matematika. Polya (2004) membagi langkah pemecahan masalah menjadi 4 tahap, yaitu 1) understanding the 
problem, 2) devising a plan, 3) carrying out the plan, dan 4) looking back. Sebelum memahami masalah, seseorang harus memahami pernyataan pada masalah. understanding the problem dapat diketahui dengan menyatakan masalah dengan menggunakan bahasanya sendiri. Ketika menghadapi masalah, kita harus mengetahui informasi masalah, menuliskan hal yang diketahui dan menghubungkan pengetahuan yang dimiliki dengan informasi yang ada pada masalah. Langkah selanjutnya adalah devising a plan yaitu memikirkan ide/rencana penyelesaian masalah yang dapat diperoleh dari pengetahuan sebelumnya. Langkah ketiga adalah carrying out the plan yaitu menggunakan rencana yang telah ditentukan tersebut untuk menyelesaikan masalah yang dihadapi. Langkah terakhir adalah looking back yaitu memeriksa kembali hasil dan langkah yang diperoleh. Ketika siswa berada pada langkah ini, maka siswa tersebut telah menggabungkan pengetahuan dan membangun kemampuannya dalam memecahkan masalah.

Berdasarkan penelitian Nurjannah (2016) diperoleh bahwa proses pemecahan masalah tidak selalu berjalan mulus. Hal tersebut dikarenakan kemampuan setiap individu berbeda. Ada siswa menilai pelajaran matematika itu sulit untuk diselesaikan, ada juga siswa lain yang menilai bahwa matematika itu mudah. Pengalaman belajar dalam matematika sangat dibutuhkan karena perbedaan kemampuan sangat mempengaruhi proses pemecahan masalahnya.

Menurut Purwanto (2014:141) bahwa "tiap orang mempunyai sikap yang berbeda-beda terhadap sesuatu perangsang". Perangsang yang dimaksud disebabkan dari berbagai faktor seperti adanya perbedaan pengalaman, pengetahuan, dan juga situasi lingkungan. Menurut Cohen (2008:1)

"Each type is one part of the three dimensions of personality he identified: extroversion-introversion, sensing-intuition and thinking-feeling. His work was expanded by Isabel Myers-Briggs and her mother, Katharine Briggs who added a fourth dimension judging-perceiving and developed the Myers Briggs Type Indicator (MBTI)".

Dapat dikatakan bahwa, Katharine dan Briggs menjabarkan tipe kepribadian menurut teori Jung dibagi menjadi empat skala preferensi yaitu, 1) kecenderungan individu memusatkan perhatiannya (extrovert-introvert), (2) cara individu menerima informasi dari luar (sensingintuition), (3) cara individu membuat keputusan (thinking-feeling), dan (4) cara individu dalam mengamati dan menilai (judging-perceiving). Berdasarkan pada empat skala preferensi tersebut, Jung mengkonsepkan tipe kepribadian secara panjang lebar dengan sebutan "extroversion" dan "introversion".
Menurut Boeree (2006:73) "introverts are people who prefer their internal world of thought, feelings, fantasies, dreams, and so on, while extroverts prefer the external world of things and people and activities". Dengan kata lain, dapat dikatakan bahwa orang introvert lebih menyukai dunia internal atau pemikiran, perasaan, fantasi, mimpi, dan sebagainya. Sementara orang ekstrovert lebih memilih dunia eksternal atau lingkungan di luar dirinya. Dalam proses pembelajaran pasti ada siswa yang berkepribadian extrovert dan introvert, namun kurang diperhatikan guru. Sementara itu, tanpa disadari hal tersebut berpengaruh dalam pengambilan keputusan untuk menarik suatu kesimpulan atas apa yang dipelajari. Kesalahan dalam penarikan kesimpulan atas apa yang dipelajari berpengaruh terhadap hasil belajar siswa di sekolah. Hal tersebut sesuai dengan penjelasan sebelumnya, adanya perbedaan kepribadian turut ambil bagian terhadap perbedaan proses berpikir kreatif dalam menyelesaikan masalah matematika.

Berdasarkan penjelasan yang telah dipaparkan di atas, maka peneliti tertarik untuk melakukan penelitian tentang "Proses Berpikir Kreatif Siswa SMP Berdasarkan Tahapan Wallas dalam Memecahkan Masalah Matematika ditinjau dari Tipe Kepribadian EkstrovertIntrovert".

\section{METODE}

Penelitian ini merupakan penelitian deskriptif dengan pendekatan kualitatif. Penelitian ini bertujuan untuk mendeskripsikan proses berpikir kreatif siswa berdasarkan tahapan Wallas dalam memecahkan masalah matematika ditinjau dari tipe kepribadian ekstrovert dan introvert.

Penelitian ini dilakukan pada siswa kelas VIII. Subjek yang terpilih yakni satu siswa bertipe kepribadian ekstrovert dan satu siswa bertipe kepribadian introvert. Dalam penelitian ini tidak didasarkan pada perbedaan gender, tetapi murni akibat perbedaan kepribadian ekstrovert dan introvert dan memiliki keterbukaan dan kelancaran komunikasi lisan. Agar tidak terjadi perbedaan pemahaman subjek yang satu dengan yang lainnya, maka subjek yang dipilih laki-laki semua atau perempuan semua.

Instrumen data dalam penelitian ini adalah tes penggolongan tipe kepribadian, Tugas Pemecahan Masalah (TPM), dan pedoman wawancara. Tes penggolongan tipe kepribadian digunakan untuk mengetahui tipe kepribadian siswa. Tugas pemecahan masalah digunakan untuk mengetahui proses berpikir kreatif siswa dalam memecahkan masalah matematika. Tugas pemecahan masalah dalam penelitian ini adalah soal pemecahan masalah matematika yang berkaitan dengan sistem persamaan linear dua variabel karena memiliki beberapa strategi yang dipergunakan untuk 
mencari penyelesaian sehingga dapat menumbuhkan dan melatih kemampuan proses berpikir kreatif siswa. Wawancara digunakan untuk memperoleh informasi yang tidak diperoleh pada data hasil tugas pemecahan masalah.

Teknik pengumpulan dan analisis data dalam penelitian ini dilakukan dengan menggunakan dua metode yaitu metode tugas dan metode wawancara. Analisis data juga dua yakni data hasil TPM dan hasil wawancara. Analisis data pada penelitian ini mengacu pada tahapan analisis data kualitatif Milles \& Huberrman (2007) yang terdiri dari empat tahap yaitu (1) mentranskripkan data, (2) mereduksi data, (3) menyajikan data, dan (4) menarik kesimpulan.

\section{HASIL DAN PEMBAHASAN}

Penelitian dilaksanakan di SMP Negeri 1 Gresik pada semester genap tepatnya di bulan April 2019 tahun pelajaran 2018/2019. Penelitian ini dilaksanakan di kelas VIII-G SMP Negeri 1 Gresik yang berjumlah 32 siswa namun pada saat penelitian terdapat satu siswa tidak masuk dikarenakan ijin sakit. Sehingga siswa yang mengikuti penelitian 31 siswa. Proses berpikir kreatif yang digunakan menurut Wallas dengan tahapan-tahapan meliputi tahap preparation, incubation, illumination, dan verification.

Hasil dalam penelitian ini menunjukkan bahwa pada proses berpikir kreatif siswa dalam memecahkan masalah matematika subjek tipe kepribadian ekstrovert pada tahap persiapan, subjek telah mengidentifikasi masalah dengan memahami dan membaca soal sebanyak dua kali. Subjek dapat menjelaskan permasalahan dengan kalimatnya sendiri, serta subjek dapat menyebutkan informasi yang diketahui dan ditanyakan. Setelah mengidentifikasi dan menyebutkan informasi masalah, kemudian subjek mencoba mengaitkan informasi yang ada pada soal dan menjelaskan bahwa soal tersebut mengenai materi SPLDV. Subjek juga memikirkan ide yang akan digunakan dalam menyelesaikan masalah dengan cara eliminasi dan substitusi untuk langkah awalnya, dan untuk langkah selanjutnya subjek masih kebingungan dalam menentukan keuntungan maksimal. Hal tersebut juga menunjukkan aspek berpikir kreatif fluency. Setelah memikirkan ide, menurut subjek tidak ada cara lain untuk menyelesaikan masalah tersebut selain memakai langkah awal SPLDV karena untuk mencari harga setiap barang dengan dua persamaan. Hal tersebut juga menunjukkan aspek berpikir kreatifflexibility. Hal ini sejalan dengan Munandar (2014) yang menyatakan bahwa tahap dimana individu dapat mengidentifikasi masalah yang diberikan dan dapat menentukan data dari masalah tersebut.

Pada tahap inkubasi, subjek mengalami titik jenuh dan tidak dapat menemukan solusi dan akhirnya ke toilet dengan alasan memikirkan solusi tersebut. Subjek juga tidak memikirkan solusi tetapi memikirkan hal lain ketika berada di toilet namun setelah itu subjek sadar dan terus berusaha memikirkan ide untuk memecahkan masalah tersebut yang akan terlihat pada tahap iluminasi. Hal ini sejalan dengan Munandar (2014) yang menyatakan bahwa tahap dimana individu berhenti sejenak untuk tidak memikirkan masalahnya dan perhatiannya fokus ke hal lain.

Pada tahap iluminasi, subjek menggunakan materi SPLDV untuk memecahkan permasalahannya. Subjek juga menemukan ide kunci dan mengembangkannya dalam menyelesaikan masalah dengan menemukan solusi untuk mencari keuntungan maksimal yaitu dengan melihat perbandingan yang sudah diketahui soal dan subjek menyelesaikan persoalan yang masih belum terpikirkan di tahap inkubasi, hal tersebut juga menunjukkan aspek berpikir kreatif originality dan elaboration. Hal ini sejalan dengan Munandar (2014) yang menyatakan bahwa tahap dimana individu memperoleh inspirasi baru. Tahap ini dapat dikatakan sebagai timbulnya "insight".

Pada tahap ini verifikasi, subjek telah mempergunakan dan melaksanakan ide sesuai yang ditetapkan pada tahap sebelumnya, hal tersebut menunjukkan aspek berpikir kreatif elaboration. Subjek tidak menuliskan solusi jawaban secara detail seperti penjelasan saat wawancara, namun subjek menjelaskan bagaimana proses mengerjakan soal tersebut dengan baik dan jelas. Subjek juga tidak memeriksa kembali langkah-langkah dan hasil perhitungannya karena sudah yakin dengan jawaban yang diperoleh, hal tersebut juga menunjukkan aspek berpikir kreatif elaboration. Subjek juga menuliskan jadi atau kesimpulan hanya pada jawaban yang sesuai dengan perintah soal.

\section{Jadi, keuntuman maksimal yarn didapit deh Fitri addaloh Rp27.600}

\section{Gambar 1 kesimpulan SE}

Berdasarkan gambar tersebut, subjek memiliki keunikan tipe kepribadian ekstrovert yang dikemukakan oleh Nuqul (2007) bahwa karakteristik tipe kepribadian ekstrovert yaitu orang yang mudah marah, gelisah, agresif, mudah menerima rangsang, berubah-ubah, impulsif, aktif, optimis, suka bergaul, dan banyak bicara. Tahap verifikasi ini menguji pemahaman yang telah diperoleh dan membuat solusi. Hal ini sejalan dengan Munandar (2014) yang menyatakan bahwa tahap verifikasi ialah tahap di mana kreasi atau ide diuji, disini juga diperlukan perhitungan dan pemikiran kreatif.

Selanjutnya proses berpikir kreatif siswa dalam memecahkan masalah matematika subjek tipe kepribadian introvert pada tahap persiapan ini, subjek telah mengidentifikasi masalah dengan memahami dan membaca soal beberapa kali sampai subjek dapat 
menjelaskan permasalahan dengan kalimatnya sendiri, serta dapat menyebutkan informasi dan pertanyaan masalah. Setelah mengidentifikasi dan menyebutkan informasi masalah, kemudian subjek mencoba mengaitkan informasi yang ada pada soal dengan materi SPLDV dan mengilustrasikan penyelesaian tersebut dalam bentuk tabel. Subjek menggunakan cara eliminasi dan substitusi dalam memikirkan ide pada langkah awal, untuk langkah kedua memilih toko mana yang paling murah dan untuk langkah ketiga menentukan keuntungan maksimalnya. Hal tersebut juga menunjukkan aspek berpikir kreatif fluency. Subjek juga menjelaskan bahwa tidak ada cara lain untuk menyelesaikan masalah tersebut selain memakai langkah awal SPLDV karena untuk mencari keuntungan harus mencari harga setiap barang dulu, kemudian dicoba hitung karena ada perbandingan yang membatasi masalah tersebut. Hal tersebut juga menunjukkan aspek berpikir kreatif flexibility. Hal ini sejalan dengan Munandar (2014) yang menyatakan bahwa tahap dimana individu dapat mengidentifikasi masalah yang diberikan dan dapat menentukan data dari masalah tersebut.

Pada tahap inkubasi, subjek mengerjakan sesuatu yang tidak ada hubungannya dengan masalah yang diberikan, dapat terlihat ketika subjek mengalami titik jenuh tetapi tetap memikirkan solusi namun sambil memainkan bolpen. Subjek tidak lagi memikirkan masalah dan penyelesaiannya secara sadar, dengan tidak memikirkan solusi tetapi memikirkan hal lain ketika memainkan bolpen namun setelah itu subjek sadar dan terus berusaha memikirkan ide untuk menyelesaikan masalah tersebut yang akan terlihat pada tahap iluminasi. Tahap inkubasi ini, masa di mana tidak ada usaha yang dipikirkan/dilakukan secara langsung untuk memecahkan masalah dan perhatian dialihkan sejenak pada hal lain. Hal ini sejalan dengan Munandar (2014) yang menyatakan bahwa tahap dimana individu berhenti sejenak untuk tidak memikirkan masalahnya dan perhatiannya fokus ke hal lain.

Pada tahap iluminasi, subjek menemukan ide kunci yang mengarahkan pada pemecahan masalah yang dihadapi setelah mengalami tahap inkubasi, dengan menggunakan materi SPLDV untuk menentukan harga setiap barang, hal tersebut juga menunjukkan aspek berpikir kreatif originality. Subjek juga mengembangkan ide kunci dan menemukan cara dalam menyelesaikan masalah, dengan menemukan solusi untuk mencari keuntungan maksimal yaitu dengan melihat perbandingan yang sudah diketahui soal dan subjek menjelaskan ketika yang dicari keuntungan maksimal berarti yang dicari selanjutnya sisa modal yang paling sedikit, hal tersebut juga menunjukkan aspek berpikir kreatif elaboration. Tahap iluminasi ini, dimana individu memperoleh sebuah penyelesaian masalah dengan munculnya ide baru. Hal ini sejalan dengan Munandar (2014) yang menyatakan bahwa tahap dimana individu memperoleh inspirasi baru. Tahap ini dapat dikatakan sebagai timbulnya "insight".

Pada tahap verifikasi, subjek telah mempergunakan dan melaksanakan ide sesuai yang ditetapkan pada tahap iluminasi, hal tersebut menunjukkan aspek berpikir kreatif elaboration. Subjek memeriksa kembali langkah-langkah dan hasil perhitungannya dari awal, hal tersebut juga menunjukkan aspek berpikir kreatif elaboration. Subjek juga menuliskan jadi atau kesimpulan secara keseluruhan, semua perbandingan yang telah ditentukan ditulis menjadi kesimpulan.

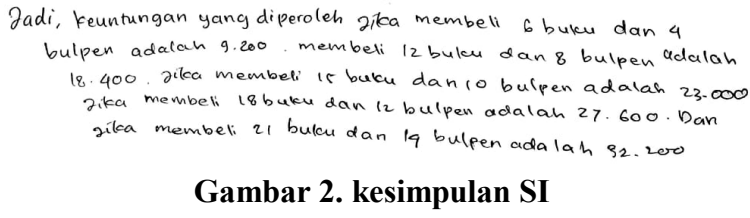

Gambar 2. kesimpulan SI

Berdasarkan gambar tersebut, subjek memiliki keunikan tipe kepribadian introvert yang dikemukakan oleh Nuqul (2007) bahwa orang dengan tipe kepribadian introvert memiliki sifat tenang, suka merawat diri, bersikap hati-hati, pemikir, kurang percaya pada keputusan yang impulsif, lebih suka hidup teratur, suka murung, kuatir, kaku, sederhana, pesimis, suka menyendiri, kurang suka bergaul, pendiam, pasif, dan berhati-hati. Tahap verifikasi ini menguji pemahaman yang telah diperoleh dan membuat solusi. Hal ini sejalan dengan Munandar (2014) yang menyatakan bahwa tahap verifikasi ialah tahap di mana kreasi atau ide diuji, disini juga diperlukan perhitungan dan pemikiran kreatif.

Persamaan dan perbedaan proses berpikir kreatif siswa dengan tipe ekstrovert dan introvert diperoleh dari hasil analisis data dan pembahasan yang dijelaskan pada Tabel 1.

\begin{tabular}{|c|c|c|c|}
\hline No & Tahap & Persamaan & Perbedaan \\
\hline 1 & Persiapan & $\begin{array}{l}\text { Kedua subjek } \\
\text { menggunakan } \\
\text { ide awal } \\
\text { SPLDV } \\
\text { dengan cara } \\
\text { eliminasi dan } \\
\text { substitusi } \\
\text { untuk } \\
\text { menyelesaikan } \\
\text { permasalahan } \\
\text { tersebut. }\end{array}$ & $\begin{array}{lr}\text { Subjek } & \text { tipe } \\
\text { ekstrovert } & \\
\text { membaca } & \text { dan } \\
\text { memahami } & \text { soal } \\
\text { sebanyak dua kali. } \\
\text { Siswa } \\
\text { introvert } \\
\text { membaca } \\
\text { memahami dan } \\
\text { beberapa kali atau } \\
\text { lebih dari dua } \\
\text { kali. }\end{array}$ \\
\hline 2 & Inkubasi & $\begin{array}{l}\text { Kedua subjek } \\
\text { mengalami }\end{array}$ & $\begin{array}{lr}\text { Subjek } & \text { tipe } \\
\text { ekstrovert } & \text { ketika }\end{array}$ \\
\hline
\end{tabular}




\begin{tabular}{|c|c|c|c|}
\hline & & $\begin{array}{l}\text { titik jenuh } \\
\text { dengan } \\
\text { berhenti } \\
\text { memikirkan } \\
\text { solusi } \\
\text { masalah, dan } \\
\text { melakukan } \\
\text { sesuatu yang } \\
\text { tidak ada } \\
\text { hubungannya } \\
\text { dengan } \\
\text { masalah. }\end{array}$ & $\begin{array}{lr}\text { tahap } & \text { ini } \\
\text { melakukan } & \\
\text { aktivitas } & \text { fisik } \\
\text { yaitu pergi } & \text { ke } \\
\text { toilet. } & \\
\text { Subjek } & \text { tipe } \\
\text { introvert ketika } \\
\text { tahap ini tidak } \\
\text { banyak bergerak } \\
\text { hanya berdiam } \\
\text { diri dengan } \\
\text { memainkan } \\
\text { bolpennya. }\end{array}$ \\
\hline 3 & Iluminasi & $\begin{array}{l}\text { Kedua subjek } \\
\text { berhasil } \\
\text { menemukan } \\
\text { ide untuk } \\
\text { menyelesaikan } \\
\text { masalah. }\end{array}$ & $\begin{array}{l}\text { Subjek tipe } \\
\text { ekstrovert } \\
\text { menuliskan } \\
\text { perbandingan } \\
\text { langsung pada } \\
\text { nilai yang dicari } \\
\text { untuk mengetahui } \\
\text { keuntungan } \\
\text { maksimalnya. } \\
\text { Subjek tipe } \\
\text { introvert } \\
\text { menuliskan } \\
\text { perbandingan } \\
\text { secara rinci dari } \\
\text { nilai yang terkecil } \\
\text { untuk mengetahui } \\
\text { keuntungan } \\
\text { maksimalnya. }\end{array}$ \\
\hline 4 & Verifikasi & $\begin{array}{l}\text { Kedua subjek } \\
\text { mampu } \\
\text { menerapkan } \\
\text { dan } \\
\text { menyelesaikan } \\
\text { masalah } \\
\text { dengan baik } \\
\text { dan sesuai } \\
\text { dengan ide } \\
\text { yang sudah } \\
\text { ditemukan } \\
\text { ditahap } \\
\text { sebelumnya }\end{array}$ & $\begin{array}{lr}\text { Subjek } & \text { tipe } \\
\text { ekstrovert } & \text { tidak } \\
\text { mengecek } & \\
\text { kembali jawaban } \\
\text { yang } & \text { telah } \\
\text { dikerjakan. } \\
\text { Subjek } \\
\text { introvert } \\
\text { mengecek } \\
\text { kembali jawaban } \\
\text { yang } \\
\text { dikerjakan. }\end{array}$ \\
\hline
\end{tabular}

\section{PENUTUP}

\section{Simpulan}

Berdasarkan hasil penelitian dan pembahasan, maka diperoleh simpulan sebagai berikut.

1) Proses Berpikir Kreatif Siswa SMP Berdasarkan Tahapan Wallas dalam Memecahkan Masalah
Matematika Ditinjau dari Tipe Kepribadian Ekstrovert

Pada tahap persiapan, subjek dapat mengidentifikasi masalah, hal tersebut dapat terlihat ketika subjek membaca soal dua kali dan memahami soal tersebut sehingga subjek dapat menjelaskan kembali menggunakan bahasanya sendiri. Subjek dapat mengumpulkan dan mengaitkan informasi pada soal, hal tersebut dapat terlihat ketika subjek dapat menjelaskan informasi yang diketahui dan ditanyakan pada soal. Subjek memikirkan ide yang juga menunjukkan aspek berpikir kreatif fluency yang digunakan dalam memecahkan masalah dengan memilih materi SPLDV (Sistem Persamaan Linear Dua Variabel) serta cara eliminasi dan substitusi untuk langkah awalnya, dan untuk langkah selanjutnya subjek masih kebingungan dalam menentukan keuntungan maksimal. Subjek tersebut menguji ide yang menunjukkan aspek berpikir kreatif flexibility.

Pada tahap inkubasi, subjek mengerjakan sesuatu yang tidak berkaitan dengan masalah yang diberikan, hal tersebut dapat terlihat ketika subjek mengalami titik jenuh dan tidak dapat menemukan solusi dan akhirnya melakukan gerakan fisik dengan alasan memikirkan solusi tersebut. Subjek juga tidak memikirkan solusi tetapi memikirkan hal lain ketika melakukan aktivitas tersebut namun setelah itu subjek sadar dan terus berusaha memikirkan ide untuk menyelesaikan masalah yang akan terlihat pada tahap iluminasi.

Pada tahap iluminasi, subjek menemukan ide kunci, hal tersebut menunjukkan aspek berpikir kreatif originality yang mengarahkan pada pemecahan masalah yang dihadapi setelah mengalami tahap inkubasi, hal tersebut dapat terlihat ketika subjek menggunakan materi yang tepat untuk menyelesaikan permasalahannya. Subjek juga mengembangkan ide kunci dan menemukan cara dalam menyelesaikan masalah, hal tersebut juga menunjukkan aspek berpikir kreatif elaboration ketika subjek menemukan solusi untuk mencari keuntungan maksimal yaitu dengan melihat perbandingan yang sudah diketahui soal dan subjek berpikir bahwa pasti ada sisa modal fitri karena tidak semua uang tersebut bisa dibelanjakan.

Pada tahap verifikasi, subjek telah menggunakan dan melaksanakan ide sesuai yang ditetapkan pada tahap iluminasi, hal tersebut menunjukkan aspek berpikir kreatif elaboration. Subjek tidak memeriksa kembali langkah-langkah dan hasil perhitungannya karena sudah yakin dengan jawaban yang diperoleh, hal tersebut juga menunjukkan aspek berpikir kreatif 
elaboration. Subjek juga menuliskan jadi atau kesimpulan hanya pada jawaban yang sesuai dengan perintah soal yaitu keuntungan maksimal yang didapatkan Fitri.

2) Proses Berpikir Kreatif Siswa SMP Berdasarkan Tahapan Wallas dalam Memecahkan Masalah Matematika Ditinjau dari Tipe Kepribadian Introvert

Pada tahap persiapan, subjek dapat mengidentifikasi masalah, hal tersebut dapat terlihat ketika subjek membaca dan memahami soal beberapa kali sampai subjek dapat menjelaskan kembali menggunakan bahasanya sendiri. Subjek dapat mengumpulkan dan mengaitkan informasi pada soal, hal tersebut dapat terlihat ketika subjek dapat menjelaskan informasi yang diketahui dan ditanyakan pada soal. Subjek juga memikirkan ide yang menunjukkan aspek berpikir kreatif fluency yang digunakan dalam menyelesaikan masalah dengan memilih materi SPLDV (Sistem Persamaan Linear Dua Variabel) serta cara eliminasi dan substitusi untuk langkah awalnya, untuk langkah kedua memilih toko mana yang paling murah dan untuk langkah ketiga menentukan keuntungan maksimalnya. Subjek tersebut menguji ide yang menunjukkan aspek berpikir kreatif flexibility.

Pada tahap inkubasi, subjek mengerjakan sesuatu yang tidak berkaitan dengan masalah yang diberikan, hal tersebut dapat terlihat ketika subjek mengalami titik jenuh tetapi tetap memikirkan solusi namun sambil memainkan alat tulisnya. Subjek tidak lagi memikirkan masalah dan penyelesaiannya secara sadar, hal tersebut dapat terlihat ketika subjek tidak memikirkan solusi tetapi memikirkan hal lain ketika memainkan alat tulisnya namun setelah itu subjek sadar dan terus berusaha memikirkan ide untuk menyelesaikan masalah tersebut yang akan terlihat pada tahap iluminasi.

Pada tahap iluminasi, subjek menemukan ide kunci, hal tersebut menunjukkan aspek berpikir kreatif originality yang mengarahkan pada pemecahan masalah yang dihadapi setelah mengalami tahap inkubasi, hal tersebut dapat terlihat ketika subjek menggunakan materi yang tepat untuk menentukan harga setiap barang. Subjek mengembangkan ide kunci dan menemukan cara dalam menyelesaikan masalah, hal tersebut juga menunjukkan aspek berpikir kreatif elaboration ketika subjek menemukan solusi untuk mencari keuntungan maksimal yaitu dengan melihat perbandingan yang sudah diketahui soal dan subjek menjelaskan ketika yang dicari keuntungan maksimal berarti yang dicari selanjutnya sisa modal yang paling sedikit.
Pada tahap verifikasi, subjek telah menggunakan dan melaksanakan ide sesuai yang ditetapkan pada tahap iluminasi, hal tersebut menunjukkan aspek berpikir kreatif elaboration. Subjek memeriksa kembali langkah-langkah dan hasil perhitungannya dari awal, hal tersebut juga menunjukkan aspek berpikir kreatif elaboration. Subjek juga menuliskan jadi atau kesimpulan secara keseluruhan, semua perbandingan yang telah ditentukan ditulis menjadi kesimpulan.

\section{Saran}

Berdasarkan simpulan di atas, saran yang dapat diberikan oleh peneliti sebagai berikut.

1) Penelitian ini mendeskripsikan proses berpikir kreatif siswa dalam memecahkan masalah matematika sistem persamaan linear dua variabel ditinjau dari tipe kepribadian, padahal dalam keberhasilan belajar tidak hanya dipengaruhi oleh tipe kepribadian saja. Untuk itu, peneliti menyarankan penelitian lanjutan ditinjau dari aspek lainya misalnya kemampuan matematika dan gaya belajar.

2) Pada penelitian ini masih banyak data/informasi yang belum tergali dengan baik mengenai proses berpikir kreatif karena pertanyaan yang diajukan peneliti pada subjek saat proses wawancara masih banyak yang terlewat. Diharapkan bagi peneliti lain yang melakukan penelitian yang sejenis agar dapat menggali informasi lebih mendalam mengenai proses berpikir kreatif dengan baik serta bisa mendapatkan informasi mengenai proses berpikir kreatif secara maksimal terutama yang belum tertulis pada jawaban subjek ini.

\section{DAFTAR PUSTAKA}

Boeree, C. G. 2006. Personality Theories: Melacak Kepribadian Anda Bersama Psikologis Dunia. Jogjakarta: Prismasophie.

Cohen, J.J. 2008. Learning Styles of Myer-Briggs Type Indicators. A Master's Thesis, School of Graduate Studies Indiana State University Terre Haute, Indiana.(online)(http://http://www.literacynet.org/lp /learn2learn/teachers/mbtindicator.html) diakses 30 Maret 2019).

Izzati, N. 2009. Berpikir Kreatif dalam Kemampuan Pemecahan Matematika. Matematis: Apa, Mengapa, dan Bagaimana Mengembangkannya Pada Peserta Didik. Makalah disajikan dalam Seminar Nasional Matematika dan Pendidikan Matematika, Bandung, 19 Desember.

Katharine, B.M \& Isabel, B.M. 2015. Perkembangan dan Penerapan Instrumen MBTI, (Online), 
(https://www.myersbriggs.org/my-mbti-personalitytype, diunduh 28 Januari 2019).

McGregor, D. 2007. Developing Thinking: Developing Learning. Maidenhead: Open University Press.

Milles, B \& Huberrman. 2007. Analisis Data Kualitatif: Buku Sumber Metode-Metode Baru. Jakarta : UI Press.

Munandar, U. 2014. Pengembangan Kreativitas Anak Berbakat. Jakarta: Rineka Cipta.

Nuqul, F.L. 2007. "Perbedaan Kepatuhan Terhadap Aturan Tinjauan Kepribadian Introvert-Ekstrovert, Jenis Kelamin dan Lama Tinggal di Ma'Had Ali Universitas Islam Negeri (UIN) Malang". Jurnal Psikoislamika. Vol. 4 No. 229-243.

Nurjannah. 2016. Proses Berpikir Kreatif Siswa SMP Berdasarkan Tahapan Wallas dalam Memecahkan Masalah Matematika Ditinjau dari Adversity Quotient (AQ). Tesis. Surabaya : UNESA.

Polya, G. 2004. How To Solve It. New Jersey: Princeton Science Library.
Purwanto, N. 2014. Psikologi Pendidikan. Bandung: Remaja Rosdakarya.

Santrock, J.W. 2014. Psikologi Pendidikan. Edisi 5 Buku 2. Terjemahan: Harya Bhimasena. Jakarta: Salemba Humanika.

Silver, F. 1997. "Fostering Creativity Though Instruction Rich in Mathematical Problem Solving and Problem Posing”. Journal ZDM Mathematics Education. Vol. 29 (3): hal. 76-80.

Siswono, T.Y.E. 2007. "Meningkatkan Kemampuan Berpikir Kreatif Siswa Melalui Pemecahan Masalah Tipe What's Another Way". Jurnal Pendidikan Matematika Transformasi. Vol. 1 (1), Oktober. ISSN: 1978-784.

Siswono, T.Y.E. 2008. Model Pembelajaran Matematika Berbasis Pengajuan Masalah dan Pemecahan Masalah Untuk Meningkatkan Kemampuan Berpikir Kreatif. Surabaya: Universitas Negeri Surabaya University Press.

Wallas, G. 2014. The art of thought. England: Solis Press. 